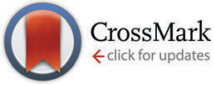

Cite this: Chem. Commun., 2017. 53, 1389

Received 28th October 2016 Accepted 28th December 2016

DOI: $10.1039 / \mathrm{c} 6 \mathrm{cc} 08670 \mathrm{e}$

www.rsc.org/chemcomm

\section{Synthesis and biophysical analysis of modified thymine-containing DNA oligonucleotides $\dagger$}

\author{
F. Kawasaki, ${ }^{a}$ P. Murat, ${ }^{a}$ Z. Li, ${ }^{a}$ T. Santner ${ }^{a}$ and S. Balasubramanian ${ }^{a b c}$
}

We report the synthesis of a 5-formyl-2'-deoxyuridine $(5 \mathrm{fU})$ phosphoramidite and the preparation of oligonucleotides comprising all known, naturally observed eukaryotic thymidine modifications. Biophysical characterization of the synthetic oligonucleotides indicates that $5 \mathrm{fU}$, but not the other T-derivatives, can alter DNA structures.

Natural chemical modifications to DNA nucleobases have the potential to influence biological events. Previous reports on cytosine $(C)$ modifications have suggested regulatory roles for 5-hydroxymethylcytosine $(5 \mathrm{hmC})$ and 5 -formylcytosine $(5 \mathrm{fC})$ in the active demethylation of 5-methylcytosine $(5 \mathrm{mC})$, and also via protein recruitment during cell differentiation and development in mammals. ${ }^{1}$ The less studied thymine (T) modifications (Scheme 1A) exist in the genome of eukaryotic cells and may also have biological functions. 5-Hydroxymethyluridine ( $5 \mathrm{hmU}$ ) can be generated from $\mathrm{T}$ by the action of ten-eleven translocation (TET) enzymes in mouse embryonic stem cells and can influence the recruitment of proteins. ${ }^{2} 5 \mathrm{hmU}, 5$-formyluridine ( $5 \mathrm{fU}$ ) and base $\mathrm{J}$ (ß-glucosylated $5 \mathrm{hmU}$ ) co-exist in the DNA of eukaryotic parasite genomes, where base $\mathrm{J}$ is proposed to act as an epigenetic mark affecting Pol II transcription and gene expression. ${ }^{3}$ Although originally reported as a product of oxidative DNA damage, ${ }^{4}$ recent studies suggest that $5 \mathrm{fU}$ may also arise via enzymatic oxidization of $5 \mathrm{hmU} .^{5} 5 \mathrm{fU}$ has been reported to disrupt the sequence-specific interactions between DNA and the transcription factor $\mathrm{NF \kappa B},{ }^{6}$ suggesting a role in modulating protein-DNA interactions. It also induces mutations and serves as a substrate for DNA glycosylases in the formation of abasic sites, ${ }^{7,8}$ thereby contributing to genomic instability.

\footnotetext{
${ }^{a}$ Department of Chemistry, University of Cambridge, Lensfield Road, Cambridge CB2 1EW, UK. E-mail: sb10031@cam.ac.uk

${ }^{b}$ Cancer Research UK Cambridge Institute, Li Ka Shing Centre, Robinson Way, Cambridge CB2 ORE, UK

${ }^{c}$ School of Clinical Medicine, University of Cambridge, Cambridge CB2 OSP, UK $\dagger$ Electronic supplementary information (ESI) available: Experimental protocols, supplementary figures, and characterization of synthetic compounds. See DOI: $10.1039 / \mathrm{c} 6 \mathrm{cc} 08670 \mathrm{e}$
}

A

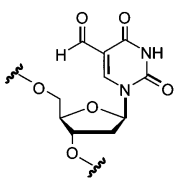

$5 \mathrm{fU}$

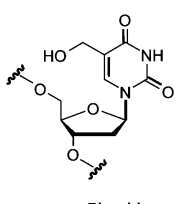

$5 \mathrm{hmU}$

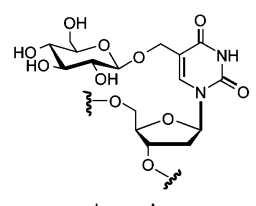

base $\mathrm{J}$
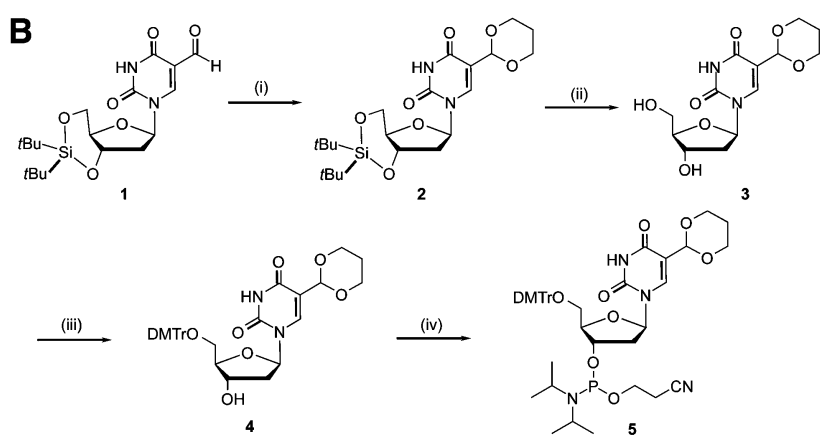

Scheme 1 Chemical structure of eukaryotic thymidine modifications and synthesis of the 5-formyl-2'-deoxyuridine phosphoramidite. (A) Structure of $5 \mathrm{hmU}, 5 \mathrm{fU}$ and base J. (B) Synthesis of the $5 \mathrm{fU}$ phosphoramidite: (i) $\mathrm{HO}\left(\mathrm{CH}_{2}\right)_{3} \mathrm{OH}, \mathrm{TiCl}_{4},(\mathrm{EtO})_{3} \mathrm{CH}, \mathrm{CH}_{2} \mathrm{Cl}_{2}, 0{ }^{\circ} \mathrm{C}, 1 \mathrm{~h}, 80 \%$; (ii) HF.pyridine, THF, $0^{\circ}$ to $\mathrm{rt}, 1 \mathrm{~h}, 99 \%$; (iii) $\mathrm{DMTrCl} \mathrm{Et}_{3} \mathrm{~N}$, pyridine, $\mathrm{rt}, 4 \mathrm{~h}, 92 \%$; (iv) $\mathrm{ClPN}(\mathrm{iPr})_{2}\left(\mathrm{OCH}_{2} \mathrm{CH}_{2} \mathrm{CN}\right), \mathrm{Et}_{3} \mathrm{~N}, 0{ }^{\circ} \mathrm{C}$ to rt, $3 \mathrm{~h}, 57 \%$.

The introduction of an extra chemical group can modulate hydrophobic and hydrogen-bonding interactions resulting in potential changes in the structure, stability and flexibility of the DNA double helix, which may in turn influence DNA recognition and biological functions. ${ }^{9}$ We recently reported a crystal structure of a $5 \mathrm{fC}$-containing DNA dodecamer showing that $5 \mathrm{fC}$ alters the geometry of the grooves and base pairs associated with the modified base, leading to local helical underwinding of a DNA duplex. ${ }^{10}$ The findings for $5 \mathrm{fC}$ suggest that formyl substitution can profoundly alter the properties of DNA, prompting us to explore the consequences of $5 \mathrm{fU}$ modifications on DNA. Previous studies showed that single alteration of $\mathrm{T}$ to $5 \mathrm{fU}$ does not significantly affect the B-DNA conformation of a DNA double helix with the effect on DNA stability varied by sequences and conditions, ${ }^{8,11,12}$ which calls for a further study in more sequence 
contexts as well as higher $5 \mathrm{fU}$ density. Herein we report a robust synthetic route to a $5 \mathrm{fU}$ phosphoramidite, which allows the synthesis of oligonucleotides bearing multiple $5 \mathrm{fUs}$ together with all known T-modifications. We also report biophysical studies to assess the effect of $5 \mathrm{fU}$, as compared to other T modifications, on the stability and structure of DNA. We found that $5 \mathrm{fU}$ can substantially affect both the structure and the stability of double-stranded DNA and can promote the formation of alternative secondary structures.

We developed a route to the $5 \mathrm{fU}$ phosphoramidite (Scheme 1B) that allows efficient synthesis of oligodeoxynucleotides (ODNs) with multiple $5 \mathrm{fU}$ modifications in addition to other T-modifications. A common strategy to introduce 5 fU to ODNs utilizes a phosphoramidite with a protected 1,2-diol group, which is then converted to the formyl group by sodium periodate oxidation following oligonucleotide backbone synthesis. ${ }^{13}$ However, this strategy is inefficient for preparing ODNs with multiple formyl groups ${ }^{14}$ and is not compatible with other T modifications, notably base $\mathrm{J}$, due to uncontrolled oxidation of the glucose residue. We thus utilized a cyclic acetal group, previously used for $5 \mathrm{fC},{ }^{14}$ to protect the $5 \mathrm{fU}$ formyl group during solid phase oligonucleotide synthesis. This strategy allowed the generation of the formyl group during the deprotection step under mild acidic conditions without affecting other T modifications. Briefly, phosphoramidite $\mathbf{5}$ was prepared in 4 steps from di-tert-butylsilyl protected fdU $\mathbf{1}$, which was synthesised from 5-iodo-dU according to literature procedures (Scheme 1B). ${ }^{15}$ Activation of the formyl group using titanium tetrachloride as a Lewis acid and treatment with 1,3dihydroxypropane gave the acetal 2 in good yield (80\%). Silyl deprotection, introduction of a 4,4'-dimethoxytrityl group and standard phosphitylation gave the $5 \mathrm{fU}$ phosphoramidite building block 5, which was subsequently used to prepare oligonucleotides by standard phosphoramidite solid phase synthesis.

The cyclic acetal group introduced in ODN1 (Table 1) was readily removed in $2 \%(\mathrm{v} / \mathrm{v})$ aqueous acetic acid without any notable side reactions (Fig. 1A). The deprotection reaction also proceeded in the presence of multiple $5 \mathrm{fU}$ modifications on a single strand to give ODN2 and 3 (Table 1 and Fig. S1, ESI $\dagger$ ). Incorporation of $5 \mathrm{fU}$ was confirmed by LC-MS analysis and mononucleoside composition analysis followed by enzymatic digestion of ODNs (Fig. 1A and Fig. S1f, ESI $\dagger$ ). By combining phosphoramidite $\mathbf{5}$ with the phoshoramidites of base $\mathrm{J}$ and 5 hmU prepared using reported procedures, ${ }^{16,17}$ we were able to synthesize an ODN bearing all eukaryotic $\mathrm{T}$ modifications (5hmU, $5 \mathrm{fU}$ and base $\mathrm{J}$ ), proving the wide applicability and robustness of our synthetic strategy (Fig. 1B).

We then prepared ODNs comprising different densities of each $\mathrm{T}$ modification, ranging from one to three modifications in a single strand, to three in both strands of the DNA duplex (Table 1), and evaluated the effects of the modifications on the DNA duplexes using biophysical methods. We first assessed the thermodynamic stability of modified ODN duplexes by thermal melting UV analysis (Table 1 and Table S1, ESI $\dagger$ ). $5 \mathrm{fU}$ did not significantly affect the thermal stability of the ODN1-ODN4 duplex, the self-complementary ODN2 duplex, and the ODN3ODN5 duplex. On the other hand, multiple 5hmU modifications
Table 1 Sequence and melting temperature of ODNs

\begin{tabular}{lcc}
\hline$X$ & $Y$ & $T_{\mathrm{m}}\left({ }^{\circ} \mathrm{C}\right)^{a, b, c}\left(\Delta T_{\mathrm{m}}\right.$ bas \\
\hline ODN1: & $5^{\prime}$-ATCGCAXGTA-3' \\
ODN4: & $3^{\prime}$-TAGCGYACAT-5' \\
$\mathrm{T}$ & $\mathrm{T}$ & \\
$5 \mathrm{fU}$ & $5 \mathrm{fU}$ & $43.5 \pm 1.1$ \\
& & $45.2 \pm 0.1(1.7)$ \\
ODN2: & $5^{\prime}$-CGXACXAGXACG-3 & \\
$\mathrm{T}$ & - & self-complementary) \\
5fU & - & $51.6 \pm 0.4$ \\
$\mathrm{U}$ & - & $52.5 \pm 0.4(0.9)$ \\
5hmU & - & $50.1 \pm 0.4(-1.5)$ \\
& & $47.8 \pm 0.1(-3.8)$
\end{tabular}

ODN3: 5'-GAACXGXCXGAG-3' ODN5: $3^{\prime}$-CTTGACAGACTC-5' $\mathrm{T}$ $5 \mathrm{fU}$ $\mathrm{U}$ $5 \mathrm{hmU}$ $\begin{array}{ll}- & 49.8 \pm 0.3 \\ - & 49.4 \pm 0.1(-0.4) \\ - & 51.1 \pm 0.2(1.2) \\ - & 46.7 \pm 0.1(-3.1) \\ - & 47.9 \pm 0.2(-1.9)\end{array}$

${ }^{a}$ Mean \pm sd values of three measurements are shown. ${ }^{b} T_{\mathrm{m}}$ was measured at $5 \mu \mathrm{M}$ of each ODN in PBS. ${ }^{c}$ See the ESI for melting curves.
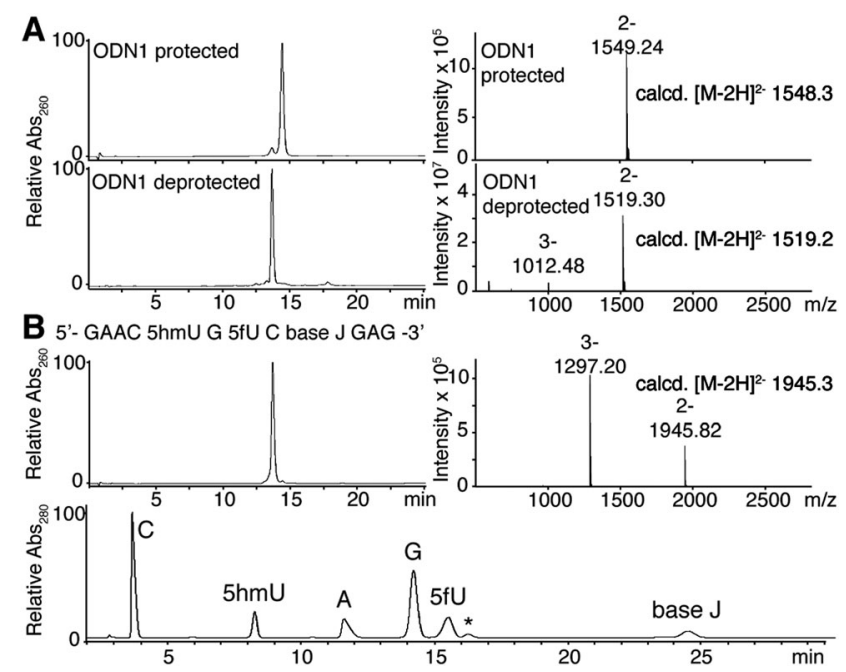

Fig. 1 (A) LC trace of ODN1 before (top) and after (bottom) deprotection together with the corresponding ESI-MS $(\mathrm{m} / \mathrm{z})$ spectra of the largest peak. The small peak at $14.3 \mathrm{~min}$ in the top LC trace was characterized as the deprotected ODN1 by MS. (B) LC trace of the ODN with three different T modifications (top, left) with ESI-MS $(\mathrm{m} / \mathrm{z})$ spectra at the largest peak (top, right) and a LC trace of the ODN enzymatically digested into mononucleosides (bottom). The peak marked * is derived from the digestion buffer.

were found to destabilize duplexes, which may be due to the hydroxyl group substitution disrupting water-mediated hydrogen bonding in the major groove. The CD spectrum of the ODN1ODN4 duplex containing just one modification $(\mathrm{X}=\mathrm{T}, \mathrm{dU}, 5 \mathrm{hmU}$ or $5 \mathrm{fU}$ ) on one strand showed patterns characteristic of B-form DNA, suggesting that a single substitution by any $\mathrm{T}$ modification does not significantly affect the duplex structure (Fig. S2A, ESI $\dagger$ ). This result agrees with a previous study, where crystal structures of short duplexes with a single $5 \mathrm{fU}$ residue demonstrated a B-DNA structure. ${ }^{12,18}$ Interestingly, changes in the DNA structure were observed when increasing the density of $5 \mathrm{fU}$. When $5 \mathrm{fU}$ was introduced to both ODN1 and ODN4 $(\mathrm{X}=\mathrm{Y}=5 \mathrm{fU})$, the $\mathrm{CD}$ 


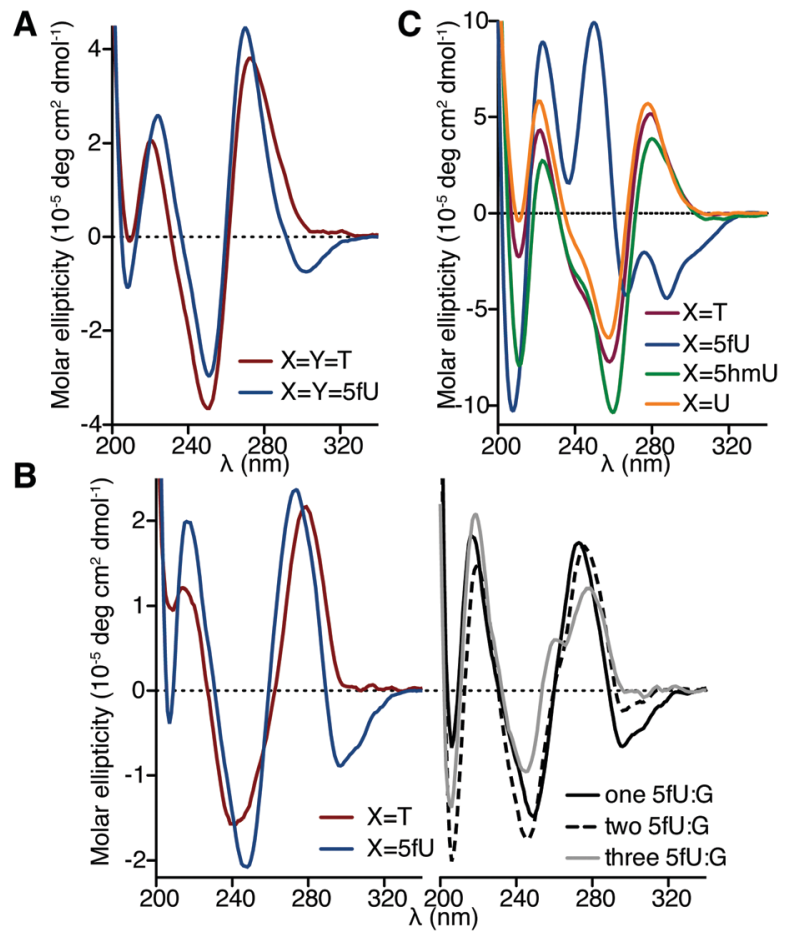

Fig. $2 \mathrm{CD}$ spectra of ODNs at $\mathrm{pH}$ 7.2. (A) ODN1-ODN4 duplexes. (B) ODN3-ODN5 duplex (left) and 5fU-containing ODN3-ODN5 duplex with one (annealed to $5^{\prime}$-CTCAGGCAGTTC-3'), two (annealed to $5^{\prime}$-CTCG GACGGTTC-3'), and three (annealed to $5^{\prime}$-CTCGGGCGGTTC-3') 5fU:G pairs (right). (C) Self-complementary ODN2 duplex.

spectrum of ODN1-ODN4 duplex displayed an absorbance band with negative ellipticity in the near-UV region (Fig. 2A). The CD spectrum of 5fU-containing the ODN3-ODN5 duplex also displayed a similar absorption pattern (Fig. 2B, left), which was not observed in the corresponding spectra of the counterparts comprising T, U, 5hmU or base J (Fig. 2B, left and Fig. S2B, $\mathrm{ESI} \dagger$ ). The CD spectrum of the self-complementary ODN2, bearing three $5 \mathrm{fU}$ modifications per strand, displayed a broad negative ellipticity band in the near-UV region $(\lambda>260 \mathrm{~nm})$, two positive ellipticity bands around $250 \mathrm{~nm}$ and $223 \mathrm{~nm}$, and a sharp negative ellipticity band around $210 \mathrm{~nm}$ (Fig. 2C). These features in the $\mathrm{CD}$ spectra are distinct from the characteristic B-DNA observed for its T, U, and 5hmU counterparts (Fig. 2C) and suggest a significant structural alteration as a result of formylated nucleobases. A negative ellipticity band in the near-UV region was also observed previously for 5 fC-containing dodecamers, ${ }^{10}$ which adopt a non-B form DNA structure. Although there has been no theoretical premise to correlate this CD spectra signature with specific DNA structural changes so far, the similarity in CD signatures suggests that the presence of $5 \mathrm{fU}$ also leads to a non B-DNA double helix. This negative band was not observed at $\mathrm{pH} 3.5$ and decreased at $\mathrm{pH} 8.6$ (Fig. S2C, ESI $\dagger$ ), implying that the contribution of $5 \mathrm{fU}$ to the DNA structure of ODN2 is pH-dependent.

We then assessed the effect of $5 \mathrm{fU}$ on duplexes with T:G mismatches, since $5 \mathrm{fU}$ can potentially pair with $\mathrm{G}$ via wobble base pair formation through its tautomer. ${ }^{19,20}$ The negative absorbance band in the CD spectra of 5fU-containing the
ODN3-ODN5 duplex became less apparent by increasing numbers of $\mathrm{G}$ opposite to $5 \mathrm{fU}$ (Fig. 2B, right). This observation suggests that $5 \mathrm{fU}$ affects the DNA duplex structure when stably paired with its complementary nucleobase A and has less impact when paired with $\mathrm{G}$ or partially unpaired. Additionally, the decrease in the thermal stability of 5fU-modified ODN3 on introducing $5 \mathrm{fU}: \mathrm{G}$ pairs was larger than that of the non-modified counterparts under near physiological conditions (Fig. S3, ESI $\dagger$ ), indicating that $5 \mathrm{fU}$ further destabilizes DNA duplexes bearing T:G mismatches in spite of its capacity to base pair with G. The observed destabilization of DNA in 5fU:G contexts and the structural alteration of DNA in 5fU:A contexts may have relevance to the mutagenic properties of $5 \mathrm{fU} .^{7}$

Modified Ts are enriched at the GGGTTA telomeric repeats of Trypanosomatid genomes. ${ }^{21}$ The GGGTTA repeats potentially fold into G-quadruplexes, single-stranded DNA structures comprising stacked guanine tetrads and loops in between. ${ }^{22}$ We therefore studied the effect of $5 \mathrm{fU}$ on ODNs with the GGGTTA telomeric repeat (ODN6) either paired with its C-rich complementary sequence (ODN7) or single-stranded (Table 2 and Table S1, $\mathrm{ESI} \dagger$ ). UV thermal melting studies showed that the introduction of $5 \mathrm{fU}$ in this specific context decreases the melting temperature of the duplex (Table 2).

Upon the introduction of three $5 \mathrm{fU}$ modifications on both strands of the ODN6-ODN7 duplex, we observed a negative band in the near-UV region of the corresponding CD spectrum consistent with previous observations for other ODNs (Fig. 3A, top). When annealed in the absence of its complementary sequence, regardless of the presence of modifications, ODN6 displayed CD spectra characteristic of antiparallel quadruplexes (a positive maximum at $295 \mathrm{~nm}$ and a negative minimum at $260 \mathrm{~nm}$ ) and hybrid quadruplexes (a positive maximum at $295 \mathrm{~nm}$ and a shoulder at $260 \mathrm{~nm}$ ) in the absence or the presence of $\mathrm{KCl}$ respectively (Fig. 3A, bottom). ${ }^{23}$ While the introduction of $5 \mathrm{fU}$ modifications did not significantly affect the CD spectra of the G-quadruplex formed by ODN6, it increased the thermal stability of the G-quadruplex by $4.6{ }^{\circ} \mathrm{C}$ (Table 2). This increased thermal stability of single-stranded G-quadruplex motifs may contribute to destabilizing the DNA duplex formed by the telomeric sequence in favour of a G-quadruplex structure. We used $1 \mathrm{D}{ }^{1} \mathrm{H}$ NMR spectroscopy to further investigate the structure of G-quadruplexes

Table $2 T_{m}$ of ODNs in the GGGTTA/TAACCC context

\begin{tabular}{|c|c|c|}
\hline$X$ & $Y$ & $T_{\mathrm{m}}{ }^{a}\left(\Delta T_{\mathrm{m}}\right.$ based on $\mathrm{T}$ control $)$ \\
\hline \multicolumn{3}{|c|}{ ODN6: 5'-AGGGXTAGGGXTAGGGXTAGGGT-3' } \\
\hline \multicolumn{3}{|c|}{ ODN7: 3'-TCCCAAYCCCAAYCCCAAYCCCA-5' } \\
\hline $\mathrm{T}$ & $\mathrm{T}$ & $68.8 \pm 0.1^{b}[62.6 \pm 0.2]^{c}$ \\
\hline $5 \mathrm{fU}$ & $5 \mathrm{fU}$ & $63.3 \pm 1.3(-5.5)^{b}[55.6 \pm 0.6(-7.0)]^{c}$ \\
\hline \multicolumn{3}{|c|}{ ODN6 (G-quadruplex) } \\
\hline $\mathrm{T}$ & - & $63.2 \pm 0.2^{d}$ \\
\hline $5 \mathrm{fU}$ & - & $67.8 \pm 0.3(4.6)^{d}$ \\
\hline \multicolumn{3}{|c|}{ 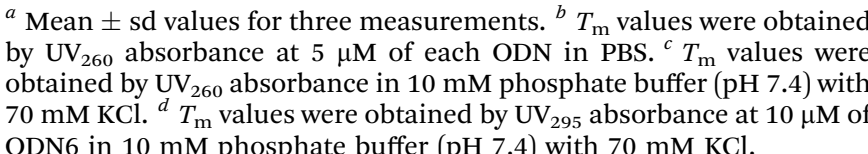 } \\
\hline
\end{tabular}


A

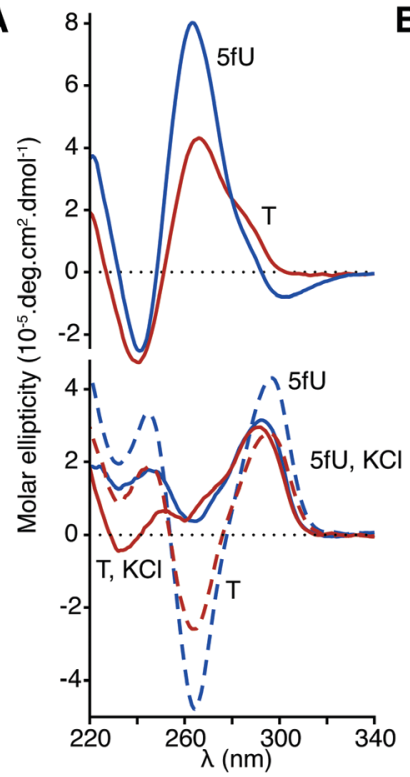

B

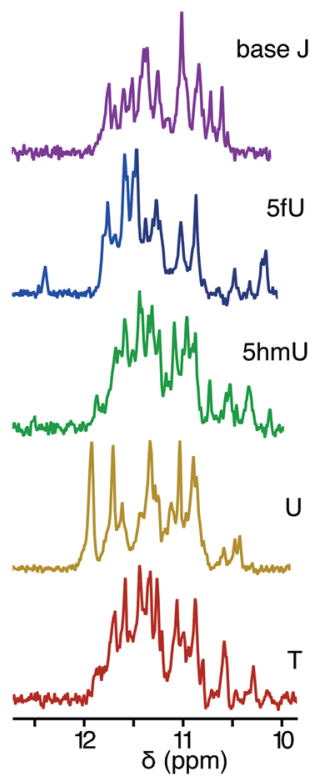

Fig. 3 CD spectrum and NMR spectra of ODNs in the GGGTTA/TTACCC context. (A) ODN6-ODN7 duplex in PBS (top) and single stranded ODN6 in the presence ( $75 \mathrm{mM}$, solid line) or absence (dashed line) of $\mathrm{KCl}$ at $\mathrm{pH} 7.4$ (bottom). Spectra of $5 \mathrm{fU}$ modified ODNs are in blue and T controls are in red. (B) $1 \mathrm{H}$ NMR spectra $(500 \mathrm{MHz})$ of ODN6 in the presence of $100 \mathrm{mM}$ $\mathrm{KCl}$ at $\mathrm{pH} 7.4$.

formed by ODN6 containing different $\mathrm{T}$ modifications. While imino proton signals characteristic of G-quadruplexes (10-12 ppm) were observed regardless of the presence of any modifications, their patterns varied in each T modified ODN6 (Fig. 3B). Telomeric DNA is known to fold into a mixture of G-quadruplex conformers, ${ }^{22}$ and the observed variations suggest that the introduction of modified Ts in the loops affects the equilibrium between the different conformers. The ${ }^{1} \mathrm{H}$ NMR spectrum of the 5fU-modified ODN6 displayed additional peaks at $12.5 \mathrm{ppm}$ as well as some upfieldshifted peaks. These peaks broadened at elevated temperatures (Fig. S4, ESI $\dagger$ ), suggesting that imino protons corresponding to these peaks are not involved in the formation of the G-tetrads. This result suggests that $5 \mathrm{fU}$ introduces extra $\mathrm{H}$-bond interactions, which may result in stabilizing the G-quadruplex motif. Taken together these observations suggest that the $5 \mathrm{fU}$ may have a specific function associated with the telomere structure.

In conclusion, the synthesis of DNA oligonucleotides comprising various eukaryotic $\mathrm{T}$ modifications has enabled us to reveal that the formyl group of $5 \mathrm{fU}$ has a distinct ability to influence the structure and the stability of DNA, though the degree of its contribution to DNA structures was dependent on its local density. This, taken together with the previously reported $5 \mathrm{fC}$ mediated DNA structure

alteration, suggests that formylation may generally regulate the DNA structure.

This work was supported by the following grants: the Wellcome Trust (099232/Z/12/Z), Cancer Research UK (C14303/A17197), ERC Advanced grant (PM), Herchel Smith Funding and A*STAR (ZL).

\section{Notes and references}

1 H. Wu and Y. Zhang, Cell, 2014, 156, 45-68.

2 T. Pfaffeneder, F. Spada, M. Wagner, C. Brandmayr, S. K. Laube, D. Eisen, M. Truss, J. Steinbacher, B. Hackner, O. Kotljarova, D. Schuermann, S. Michalakis, O. Kosmatchev, S. Schiesser, B. Steigenberger, N. Raddaoui, G. Kashiwazaki, U. Muller, C. G. Spruijt, M. Vermeulen, H. Leonhardt, P. Schar, M. Muller and T. Carell, Nat. Chem. Biol., 2014, 10, 574-581.

3 H. G. van Luenen, C. Farris, S. Jan, P. A. Genest, P. Tripathi, A. Velds, R. M. Kerkhoven, M. Nieuwland, A. Haydock, G. Ramasamy, S. Vainio, T. Heidebrecht, A. Perrakis, L. Pagie, B. van Steensel, P. J. Myler and P. Borst, Cell, 2012, 150, 909-921.

4 S. Bjelland, L. Eide, R. W. Time, R. Stote, I. Eftedal, G. Volden and E. Seeberg, Biochemistry, 1995, 34, 14758-14764.

5 W. Bullard, J. Lopes da Rosa-Spiegler, S. Liu, Y. Wang and R. Sabatini, J. Biol. Chem., 2014, 289, 20273-20282; J. E. Pais, N. Dai, E. Tamanaha, R. Vaisvila, A. I. Fomenkov, J. Bitinaite, Z. Sun, S. Guan, I. R. Correa, Jr., C. J. Noren, X. Cheng, R. J. Roberts, Y. Zheng and L. Saleh, Proc. Natl. Acad. Sci. U. S. A., 2015, 112, 4316-4321.

6 A. Kittaka, H. Takayama, M. Kurihara, C. Horii, H. Tanaka, T. Miyasaka and J. Inoue, Nucleosides, Nucleotides Nucleic Acids, 2001, 20, 669-672.

7 H. Anensen, F. Provan, A. T. Lian, S. H. Reinertsen, Y. Ueno, A. Matsuda, E. Seeberg and S. Bjelland, Mutat. Res., 2001, 476, 99-107.

8 P. Liu, A. Burdzy and L. C. Sowers, DNA Repair, 2003, 2, 199-210.

9 M. Y. Liu, J. E. DeNizio, E. K. Schutsky and R. M. Kohli, Curr. Opin. Chem. Biol., 2016, 33, 67-73.

10 E. A. Raiber, P. Murat, D. Y. Chirgadze, D. Beraldi, B. F. Luisi and S. Balasubramanian, Nat. Struct. Mol. Biol., 2015, 22, 44-49.

11 A. Ono, T. Okamoto, M. Inada, H. Nara and A. Matsuda, Chem. Pharm. Bull., 1994, 42, 2231-2237.

12 M. Tsunoda, J. Kondo, N. Karino, Y. Ueno, A. Matsuda and A. Takenaka, Biophys. Chem., 2002, 95, 227-233.

13 H. Sugiyama, S. Matsuda, K. Kino, Q.-M. Zhang, S. Yonei and I. Saito, Tetrahedron Lett., 1996, 37, 9067-9070.

14 A. S. Schroder, J. Steinbacher, B. Steigenberger, F. A. Gnerlich, S. Schiesser, T. Pfaffeneder and T. Carell, Angew. Chem., Int. Ed., 2014, 53, 315-318.

15 Q. Dai, C. X. Song, T. Pan and C. He, J. Org. Chem., 2011, 76, 4182-4188.

16 M. de Kort, P. C. de Visser, J. Kurzeck, N. J. Meeuwenoord, G. A. van der Marel, W. Ruger and J. H. van Boom, Eur. J. Org. Chem., 2001, 2075-2082.

17 L. C. Sowers and G. P. Beardsley, J. Org. Chem., 1993, 58, 1664-1665. 18 M. Tsunoda, T. Sakaue, S. Naito, T. Sunami, N. Karino, Y. Ueno, A. Matsuda and A. Takenaka, Nucleic Acids Res. Suppl., 2001, 279-280.

19 M. Yoshida, K. Makino, H. Morita, H. Terato, Y. Ohyama and H. Ide, Nucleic Acids Res., 1997, 25, 1570-1577.

20 A. Masaoka, H. Terato, M. Kobayashi, Y. Ohyama and H. Ide, J. Biol. Chem., 2001, 276, 16501-16510.

21 P. A. Genest, B. Ter Riet, T. Cijsouw, H. G. van Luenen and P. Borst, Nucleic Acids Res., 2007, 35, 2116-2124.

22 A. T. Phan, FEBS J., 2010, 277, 1107-1117.

23 J. Kypr, I. Kejnovska, D. Renciuk and M. Vorlickova, Nucleic Acids Res., 2009, 37, 1713-1725. 